\title{
The Migration of Experts and Savoir-faire
}

The Case of French Cuisine Professionals in Shanghai

Hélène Le Bail and Aël Théry

\section{(2) OpenEdition}

\section{Journals}

Electronic version

URL: http://journals.openedition.org/chinaperspectives/7482

ISSN: 1996-4617

\section{Publisher}

Centre d'étude français sur la Chine contemporaine

\section{Printed version}

Date of publication: 1 December 2017

Number of pages: 49-58

ISSN: 2070-3449

\section{Electronic reference}

Hélène Le Bail and Aël Théry, "The Migration of Experts and Savoir-faire », China Perspectives [Online], 2017/4 | 2017, Online since 01 December 2018, connection on 28 October 2019. URL : http:// journals.openedition.org/chinaperspectives/7482

This text was automatically generated on 28 October 2019

(c) All rights reserved 


\section{The Migration of Experts and Savoir-faire}

The Case of French Cuisine Professionals in Shanghai

Hélène Le Bail and Aël Théry

\section{ABSTRACTS}

This article focuses on the practice of French cuisine in Shanghai and questions the permanence of this professional niche. It combines an anthropological approach to culinary techniques with a sociological approach to workforce migration, tracing the ways in which the discourse and practices of chefs and maitres d'hôtel working in French cuisine's restaurants employ forms of ethnocultural and technical legitimacy. The case of Shanghai, a city undergoing rapid transformation in its modes of consumption, provides a clear illustration of the shifts that have occurred over the last ten years in the hierarchy of Western migrants and Chinese locals: the symbolic and material privileges offered to the former are beginning to disappear, and professional recognition is increasingly becoming based on savoir-faire and a strong work ethic.

\section{INDEX}

Keywords: China, French cuisine, migration, knowledge transfer, training 


\section{AUTHORS}

\section{HÉLÈNE LE BAIL}

Hélène Le Bail is a research fellow at Sciences Po Paris-CERI, CNRS.Sciences Po CERI, 56 rue Jacob, 75006 Paris (helene.lebail@sciencespo.fr).

\section{AËL THÉRY}

Aël Théry is a doctoral student at EHESS/TEPSIS (School for Advanced Studies in the Social Sciences), and a research assistant at ESSCA on the ANR project "Immigration and the transformation of Chinese Society.”EHESS, 54 boulevard Raspail, 750016 (ael.thery@ehess.fr). 